\title{
Lean Accounting and Throughput Accounting: An Integrated Approach
}

\section{Tatyana Vasilievna Elsukova}

\author{
Institute of management, economics and finance, Kazan Federal University (KFU)
}

Email: sci.publ@gmail.com

\section{Doi:10.5901/mjss.2015.v6n3p83}

\begin{abstract}
In conditions of increasing competition there is need for application of new production systems, new approaches to pricing, new approaches to calculation of costs for a product in the developed markets. Besides modernization of production, modernization of an enterprise management system is necessary. The traditional methods of management accounting do not cope with requirements for formation of information in modern enterprises and their management. The article presents two methods of management accounting - Lean accounting (LA) and Throughput accounting (TA) - and offers an integrated approach for its use in commercial enterprises. We study and introduce a model of integrated approach of LA+TA and note positive sides of this approach. The integrated approach will allow to generate information about costs and results of a modern enterprise more effectively than during application of separate methods.
\end{abstract}

Keywords: lean accounting, throughput accounting, management accounting, costs, commercial enterprises, integrated approach $L A+T A$, lean throughput accounting

\section{Introduction}

Two methods of management accounting considered in this article - lean accounting and throughput accounting - are modern methods of management accounting that are not studied in full. The majority of researchers compare management theories - a theory of constraints and lean production - and 6 sigma theory in addition to them (Nave D, 2002). For all management theories information must be formed, namely management accounting must be kept. Lean accounting and throughput accounting were repeatedly compared in scientific articles. For example, a complete literature review on this topic is made by such authors asUtiyama, M.H.R.,Filho, M.G. (Utiyama, M.H.R., Filho, M.G, 2013).

An overall conclusion from the literary review is thatit is impossible to say that one of the methods surpasses another, management of an enterprise shall decide on its own which of the management accounting methods suits the company more. Opinions on integration of these management accounting methods have been already expressed in literature (Najarian G, 2004.). Therefore study of an integrated approach to management accounting under the principles of lean production and a theory of constraints or LA+TA integrated approach is relevant.

\section{Model and Data}

The objective of the study is finding the points of intersection of two modern management accounting methods (Lean accounting and Throughput accounting) to create an integrated method of management accounting. The concept of lean production is introduced in many industrial enterprises throughout the world. The management system of Lean production is characterized in papers by scientists (Sokolov A.U., 2007) as well as in the management accounting standard of the USA, "Lean enterprise goals include: improving quality and customer satisfaction, creating more value for the customers, eliminating waste, reducing lead time, and reducing costs." The method of management accounting in lean enterprises is often called Value Stream Costing (VSC) because the flow of value creation is the main subject of management accounting and control (Sokolov A.U., 2007)]. In our opinion, the name of Lean accounting does not reflect complete essence of the method and is designation of the approach in accounting, but since it is generally accepted in international publications, we will adhere to this definition. Basic principles of the lean accounting method are as follows:

1. the principle of determination and removal of loss at different stages of production;

2. the principle of determination of a product value for a buyer;

3. the principle of determination of a flow of value creation;

4. the principle of continuous perfection of an accounting system.

5. the principle of integrity (integration). 
The concept of the theory of constraints (TOC) began to be introduced a little earlier. The theory of constraints is successfully being applied abroad in such big companies as Avery Dennison, Bethlehem Steel, General Motors, National Semiconductor, United Airlines, Boeing, ITT, Procter \& Gamble, IKEA, Wall-Mart, Zara. At present works are undertaken on introduction of the theory of constraints in the Russian enterprises. Besides TOC is introduced not only in production, but also in logistics, wholesale trade, and retail, human resources management.

The theory of constraints is defined as follows(Noreen E., Smith D., Mackey J.T., 1995) : «the fundamental thesis of TOC is that constraints establish the limits of performance for any system. Most organizations contain only a few core constraints. TOC advocates suggest that managers should focus on effectively managing the capacity and capability of these constraints if they are to improve the performance of their organization».

The throughput accounting (TA) method of management accounting is based on the principles of the theory of constraints, the main attention of which is given to management of constraints of the production-economic activity of the enterprise. Itsupplements this management system, providing all the necessary information to managers for management and control over the constraints of an enterprise. Basic principles of the TA method of accounting are as follows:

1. value of the product (work, service) is created at the moment of product (works, services) sale;

2. the principle of resources redeployment in places of restrictions for the purpose of Throughputmaximization;

3. the principle of urgency (management statements);

4. the principle of comparability of approaches to calculation of costs;

5. the principle of integrity (integration);

6. the principle of continuous perfection of accounting and analysis systems.

Both approaches in management accounting have similar features and differences. There is need for deeper study of these methods. According to studies of the scientists (Corbett T., 1998., Goldratt E., Cox Jeff., 1992)use of each separate method has certain advantages over traditional standard-costing, variable-costing, direct-costing, ABC and other methods of management accounting. We will try to model an integrated methodology of LA+TA (integrated approach) which will include the most efficient elements of both methods for achievement of an optimal result during maintaining accounting.

In production management the approaches of the theory of constraints and lean production (management as per flows of value creation) have many common grounds allowing the enterprises to introduce both approaches and receive additional benefits. Both the theory of constraints and lean production promote an idea of continuous improvement of theproduction flow in enterprises.

We will conduct comparative analysis of management accounting methods on the basis of the principles of the theory of constraints and cost accounting as per flows of value creation in table 1.

Table 1. Comparative analysis of TA and LA methods

\begin{tabular}{|c|c|c|}
\hline Comparisoncriterion & Throughputaccounting(TA) & Leanaccounting (LA) \\
\hline Timeofemergence & $\begin{array}{l}\text { 1988, articles by D. Galloway and D. Valdron in the journal } \\
\text { "Management accounting" (Galloway, D. Waldron, D. } \\
\text { 1988)became one of the first scientific publications on } \\
\text { exploration of the TA method }\end{array}$ & $\begin{array}{l}\text { 2004, after studies of V. Maskell and B. Bagalli "Practical } \\
\text { Lean Accounting, A Proven System for Measuring and } \\
\text { Managing the Lean Enterprise " (Maskell B.H., Baggaley B. } \\
\text { 2004) were published }\end{array}$ \\
\hline $\begin{array}{l}\text { Main developers of the } \\
\text { method }\end{array}$ & $\begin{array}{l}\text { E. Goldratt, D. Galloway, D. Valdron, T. Corbett, S. Bragg, } \\
\text { D. Dagdeil, T. Jones, E. Norin., D. Smith(Noreen E., Smith } \\
\text { D., Mackey J.T. 1995.)] }\end{array}$ & $\begin{array}{l}\text { V. Maskell, B. BagalliJ. Womack, R. Kaplan, R.Krandell. O. } \\
\text { Fume (Fiume O.J., Cunningham J.E., Adams E. 2003) }\end{array}$ \\
\hline $\begin{array}{l}\text { Management accounting } \\
\text { standards (IMA USA) }\end{array}$ & $\begin{array}{l}\text { SMA IMA "Theory of Constraints (TOC, 1999). } \\
\text { Management System Fundamentals", } 1999 .\end{array}$ & $\begin{array}{l}\text { SMA IMA "Accounting for the Lean Enterprise: Major } \\
\text { Changes to the Accounting paradigm", } 2006 .\end{array}$ \\
\hline Main task of the method & $\begin{array}{l}\text { Increase of throughput (revenue net of total variable costs), } \\
\text { cost cutting is not the key objective }\end{array}$ & $\begin{array}{l}\text { Cost cutting due to increase of flow rate, reduction of loss, } \\
\text { continuous improvement of business processes }\end{array}$ \\
\hline Object of cost accounting & $\begin{array}{l}\text { A product (work, service) is the target object of cost } \\
\text { accounting }\end{array}$ & $\begin{array}{l}\text { The object of cost accounting is a flow creating value - a set } \\
\text { of types of activity which create the product value in terms of } \\
\text { consumers }\end{array}$ \\
\hline Effect on change of costs & $\begin{array}{l}\text { The major factor influencing change of costs value } \\
\text { isconstraints of the production-economic activity of an } \\
\text { enterprise, liquidation of constraints }\end{array}$ & $\begin{array}{l}\text { Changes in costs occur after «lean transformations»: } \\
\text { removal of loss, optimization of the flow }\end{array}$ \\
\hline Classification of costs & Total variable costs, operating costs & Costs \\
\hline Costallocation & $\begin{array}{l}\text { It is not used or operating costs are distributed under } \\
\text { ABC/TBC method }\end{array}$ & $\begin{array}{l}\text { It is not used or insignificant share of costs outside the flow is } \\
\text { allocated }\end{array}$ \\
\hline Determination of cost price & $\begin{array}{l}\text { A cost price of products is estimated based on the overall } \\
\text { variable costs }\end{array}$ & A cost price of ready products is not calculated \\
\hline Reservesestimation & $\begin{array}{l}\text { The reserves are estimated based on the overall variable } \\
\text { costs (excluding costs for remuneration of labour), one of } \\
\text { the tasks is diminution of reserves }\end{array}$ & $\begin{array}{l}\text { Reserves are almost absent, production is organized as per } \\
\text { just-in-time system (exactly on time) }\end{array}$ \\
\hline
\end{tabular}




\begin{tabular}{|c|c|c|}
\hline $\begin{array}{l}\text { Reflection of costs on } \\
\text { book-keeping accounts } \\
\text { Units of measurement of } \\
\text { operating efficiency } \\
\text { indicators }\end{array}$ & $\begin{array}{l}\text { Use of management accounting accounts («Total variable } \\
\text { costs» (TVC)», Operating costs (OE), Throughput (T)) } \\
\text { Use of financial and non-financial indicators }\end{array}$ & $\begin{array}{l}\text { Use of management accounting accounts (accounts "Costs } \\
\text { of value creating flow", "Costs outside flows", etc.) } \\
\text { Major use of non-financial indicators }\end{array}$ \\
\hline Key indicators of activity & $\begin{array}{l}\text { Throughput, profit, investments into buildings, } \\
\text { constructions, reserves }\end{array}$ & $\begin{array}{l}\text { Flow rate, average costs of the flow, percentage of rejected } \\
\text { items }\end{array}$ \\
\hline $\begin{array}{l}\text { Taking } \\
\text { management decisions }\end{array}$ & $\begin{array}{l}\text { The decisions "whether to make or to buy" are taken on the } \\
\text { basis of data about change of gross value of throughput }\end{array}$ & $\begin{array}{l}\text { The decisions "whether to make or to buy" are taken on the } \\
\text { basis of information about flows }\end{array}$ \\
\hline Managementstatements & $\begin{array}{l}\text { Management statements for a month (quarter), weekly } \\
\text { planning of throughputin view of products, customers }\end{array}$ & $\begin{array}{l}\text { A weekly management profit and loss statement in view of } \\
\text { flows creating value }\end{array}$ \\
\hline
\end{tabular}

According to table 1, themanagement accountingmethods under analysis, have a lot of similar elements based on which they can be combined. Both systems are flexible, simple in administration of accounting by analyst accountants, use nonfinancial indicators of activity, track manufacturing cycle time, are not focused on determination of full cost price of production (works, services), do not allocate overhead costs, are aimed at optimization of the production flow, provide operational management statements. The conducted comparative analysis of TA and LA methods allows to determine their advantages and disadvantages, to determine possibilities of their joint use in industrial enterprises. The proposals on refinement of cost and result accounting with the use of these methods allow to use advantages of these methods and lower influence of disadvantages. Using information of the integrated approach of two modern management accounting methods will allow to manage companies more effectively in terms of changing environment and competition.

\section{Empirical Results}

On the grounds of the conducted research we propose to apply the integrated LA+TA methodology where the elements of throughput accounting method are integrated in the established management accountingmethodof lean accounting, which will significantly simplify their introduction in the enterprise. Introduction of lean production significantly alters organizational structure of the enterprises, distribution of production capacities, therefore after these changes it is already easy to change the management accounting system. At the level of inventory control the launch of small lots into production, low level of material reserves, evaluation of reserves as per overall variable costs (total variable cost) will remain in the unified methodology.

As for classification of costs during unification of LA+TA methods of management accounting,operating costs of the flow and operating costs outside the flow must be separated (as in LA method) from the sum of operating costs (under TA method) during a period. Thus their control and reduction will be more effective.

According to TA method, the rate of throughput is estimated on each product as a difference between the product price and material costs for the product. Therefore separate flow must be analyzed for each manufactured product (or a homogeneous group of products), in other words, there is distribution of operating costs for each flow creating value. Operating costs of the flow creating product value include costs for remuneration of labour and insurance installments, costs for maintenance of equipment, other total production costs. Costs outside the flow are administrative and other general running costs not related to product manufacture. These costs will reduce an overall financial balance of the company. The TA methodin classical form does not provide allocation of operating costs, but we propose to allocate operating costs of the flow in proportions to product processing time on constrainingresource for calculation of profit from each flow.

Table 2. Proposedmanagement statementof results of the enterprise "Smart" LLC for May 2014 to use an integrated methodology of LA+TA

\begin{tabular}{|c|c|c|c|c|c|c|c|}
\hline \multirow[b]{2}{*}{ № Indicators } & \multicolumn{6}{|c|}{ Flow/product } & \multirow[b]{2}{*}{$\begin{array}{l}\text { In total, } \\
\text { m.u. }\end{array}$} \\
\hline & $\begin{array}{c}\text { Universal } \\
\text { Programmable } \\
\text { Controller } \\
\text { "Standard" }\end{array}$ & $\begin{array}{l}\text { Interface block } \\
\text { the device } \\
\text { ShGS5805 }\end{array}$ & $\begin{array}{l}\text { Radiomodem } \\
\text { "Smart- } \\
\text { 160/2400" }\end{array}$ & $\begin{array}{l}\text { Radiomodem } \\
\text { "Smart- } \\
\text { 433/2400" }\end{array}$ & $\begin{array}{c}\text { Vertical } \\
\text { antenna AC } \\
5 / 8 \mathrm{VHF}\end{array}$ & $\begin{array}{c}\text { RF } \\
\text { bandpass } \\
\text { filter PF5- } \\
\text { 2VHF }\end{array}$ & \\
\hline 1 P-price of product, m.u. & 600 & 487,29 & 852,60 & 556,10 & 621,0 & 223 & \\
\hline 2 TVC -Total variable costs, m.u. (on each product.) & 299 & 183,9 & 253,32 & 78,3 & 214,2 & 69,75 & \\
\hline 3 T - Throughput, m.u (on each product) & 301 & 303,39 & 749,1 & 477,8 & 406,8 & 153,25 & \\
\hline $4 \mathrm{t}$ - build unit of production, hour & 9 & 24 & 8 & 12 & 15 & 11 & \\
\hline 5 Target value ofsales,unit. & 1200 & 50 & 594 & 200 & 70 & 55 & \\
\hline $6 \mathrm{~T}$ - throughputon the target volume, m.u & 361200 & 15169,5 & 444965,4 & 95560,0 & 28476,0 & 8428,75 & 953799,7 \\
\hline 7 Operating costs of the flow, m.u & 301052,53 & 33450,28 & 132463,1 & 66900,56 & 29269,0 & 16864,52 & 580000,0 \\
\hline 8 Profit of the flow, m.u & 60147,47 & $-18280,78$ & 312502,3 & 28659,44 & $-793,0$ & $-8435,77$ & 373799,7 \\
\hline 9 Operating costs outside the flow, m.u. & & & & & & & 70000,0 \\
\hline 10 Profit of the enterprise over the period, m.u. & & & & & & & 303799,7 \\
\hline
\end{tabular}


Scientific and Production Company "Smart" LLC is located in Kazan, Russia and is engaged in development and production of industrial electronics products. During analysis of the production flows in the enterpriseit was found out that (non- automated) the operation of assembly of finished units was limiting resource for manufacture of these products. At the same time the following management statement will be made up (table 2). Operating costs of all flows of the company have constituted 580,000 monetary units (m.u.) in the reviewed period (month) and are allocated between the flows in proportion to the product assembly time. Operating costs outside the flow have constituted 70,000 monetary units in the period (month).

Profit of each flow is calculated as a difference between throughput and operating costs of the flow. During analysis of these management statement it can be seen that three flows of six turned loss-making, although in general the enterprise achieves positive profit level for a period. Costs of these flows must be analyzed for revelation of causes of the flow loss and control over efforts for reduction of these costs. The indicators of throughput for the flows are also used during planning of the production program of the enterprise, calculation of the planned throughput of all the enterprise, and at other strategic activity indicators.

These management statement (in table 2) can be made upon the plan indicators, as well as upon the actual indicators. So during introduction of TA method into LA method we receive an integrated methodology of costs accounting and results on the flows creating values with consideration for limiting resources of the enterprise.

We will consider a model of the integrated approach which includes positive sides oflean accounting and throughput accounting methods in figure 1.

In the enterprises applying the principles of lean production, we propose to use an integrated methodology of LA+TA (lean throughput accounting). The integrated methodology is aimed at increasing the financial balance and reduction of costs, which as a result will lead to an optimal final result of all the enterprise.

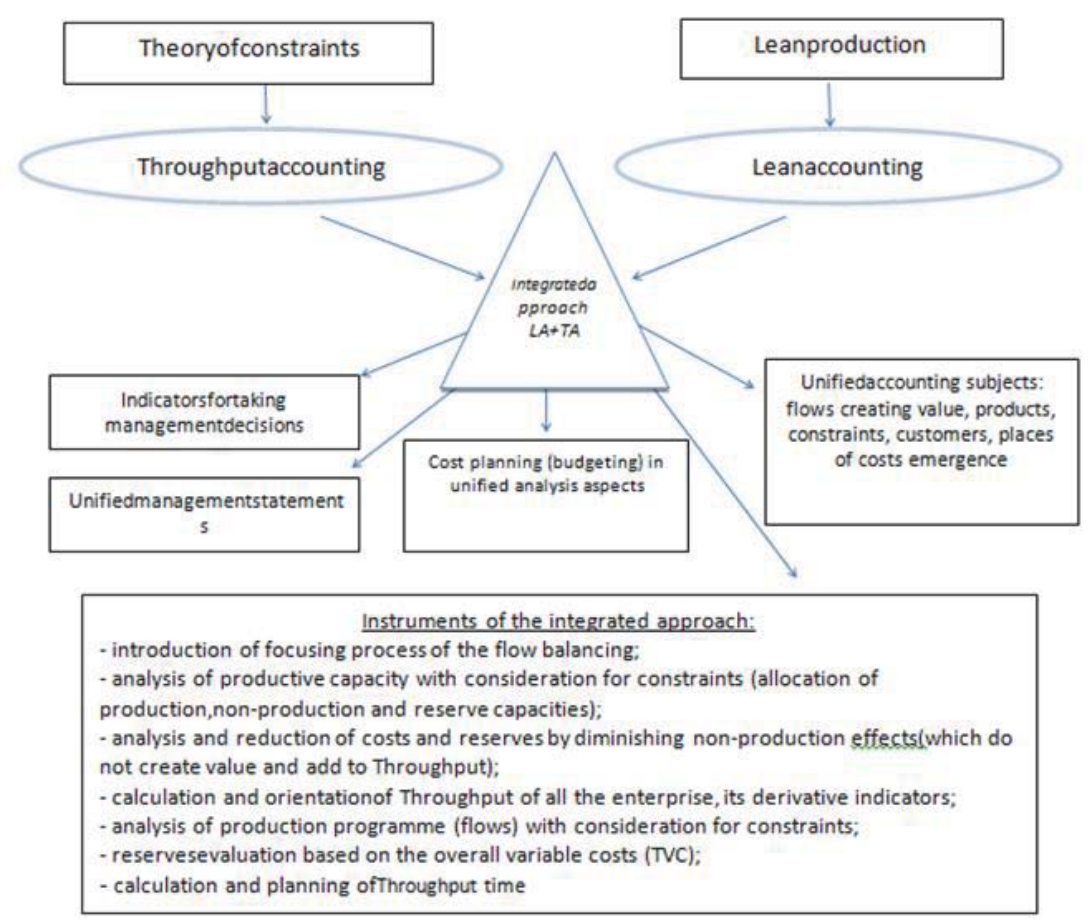

Figure 1. Model of integrated approach LA + TA

At the expense of influence of the lean accounting method aimed at analysis of costs outside the flow creating value, and the throughput accounting methodaimed at promotion of an enterprise and increase of the rate of production speedincrease of the capacity at the expense of internal reserves (without additional expenditure) is achieved. In the company under our analysis, introduction of the integrated methodology caused positively influence on financial balance of the company. Profitability of investments increases at theexpense of increase of the flow rate and increase of the constraints capacity.

The LAmethod is the main method of management accounting in lean enterprises. In the framework of industrial 
engineering theapproaches of the theory of constraints and lean productionhave many common grounds allowing the enterprises to introduce both approaches and receive additional advantages during introduction of tools of the integrated methodology. Both the theory of constraints and lean production as theories of production management promote the idea of continuous improvement of the production flow in enterprises. The key positive aspects of joint use of LA and TA methods of management accounting are as follows:

a) improvement of the production flow at the expense of reduction of manufacturing cycle time; prevention of goods overproduction (planning of launch of resources into production, minimum of reserves);

b) cancellation of local operating efficiency indicators (actual production cost and profitability on costs are replaced by new indicators - throughput and its derivatives; operating costs, investments into buildings, constructions, and reserves, non-financial and financial indicators of timely delivery of orders);

c) introduction of focusing process of the flow balancing (optimization of the production system at the expense of focusing on limiting resources of the enterprise).

\section{Results}

The management theoriesconsidered in the article - the theory of constraints (TOC) - andlean production (Lean)harmoniously supplement each other. The theory of constraints is a management approach for determination of restrictions in the flow that must be improved. The Lean methodology offers instruments of exercising technical improvements of production. The methods of management accounting can be also combined. During introduction of the principles of lean production in the enterprise it is proposed to integrate the lean accounting management accountingmethod together with the throughput accounting method, which will allow to increase the capacity of the enterprise and increase financial balance, onthe one hand, and reduce unnecessary actions and costs associated with it, on the other hand. Operating management statements for the integrated methodology are proposed in the article.

\section{Conclusions}

Use of the throughput accounting method refocuses the enterprises and their management on satisfaction of consumers' requirements and growth (extension) of business. Accounting of costs for flows creating value in lean enterprises - lean accounting - is also aimed at satisfaction of consumer demand, as well as at continuous cost cutting and optimization of the enterprise structure. The considered methods of management accounting are integrated in the proposed model (LA+TA) for more effective application in industrial enterprises of Russia and all other countries of the world.

\section{Acknowledgements}

I express gratitude to the Chair for Management Accounting and Controlling ofthe Institute of Management, Economy and Finance of Kazan (Volga region) Federal University for assistance in preparation of this article and personally to the Professor Ivashkevich V.B. and the Professor SokolovA.Yu.

\section{References}

Accounting for the Lean Enterprise: Major Changes to the Accounting paradigm. Institute of Management Accountants, 2006.

Corbett T., 1998. Throughput accounting.North river press, p.45.

Galloway, D. Waldron, D. 1988. Throughput accounting -1: The need for a new language for manufacturing. Management accounting. November: pp. 34-35.

Goldratt E., Cox Jeff. 1992. The Goal: A Process of Ongoing Improvement, North River Press Inc., p. 33.

Kaspina, R.G., L. S. Khapugina and E. A. Zakirov, 2014.Employment of activity-based costing in the process of company business model generation. Life Science Journal, 11 (8): p.357.

Maskell B.H., Baggaley B. 2004. Practical Lean Accounting, A Proven System for Measuring and Managing the Lean Enterprise - New York; Productivity Press, p.207.

Najarian G. 2004. Opposing Teams? Toward a new model of accounting in the era of lean.APICS, April.-pp.24-29.

Nave, D. 2002. How to Compare Six Sigma, Lean and the Theory of Constraints, Quality Progress Volume 35, Issue 3, March, pp.73-78

Needles Jr., B.E., A. Shigaev, M. Powers and M. L. Frigo, 2014.Operating characteristics of high performance companies: Strategic direction for management. Studies in Managerial and Financial Accounting, 28: p.38.

Noreen E., Smith D., Mackey J.T. 1995. The theory of constraints and its implications for management accounting.The North river press.p. 75.

Sokolov A.U., 2007. Formation of cost information in the system of management accounting, Moscow: Accounting, p.138-142

Theory of Constraints (TOC). Management System Fundamentals. 1999. Institute of Management Accountants.

Utiyama, M.H.R., Filho, M.G. 2013. Literature on the comparison between the theory of constraints and lean manufacturing: Review, classification, and analysis. Gestao e Producao. Volume 20, Issue 3: p. 625.

Fiume O.J., Cunningham J.E., Adams E. 2003. Real Numbers: Management Accounting in a Lean Organization. Managing Time Press, p.42. 